\title{
Massive Pulmonary Embolism in the Early Postoperative Period Following Coronary Artery Bypass Surgery
}

\author{
Koroner Baypas Cerrahisi Sonrası Erken Dönemde Gelişen
}

Masif Pulmoner Emboli ve Tedavisi

\section{Hüseyin Şaşkın, Çağrı Düzyol, Rezan Aksoy, Atike Tekeli Kunt}

Derince Eğitim ve Araştırma Hastanesi, Kalp ve Damar Cerrahisi Kliniği, Kocaeli

Asemptomatik venöz tromboembolizm koroner baypas cerrahisi sonrası şaşırtıcı olarak sık görülmektedir. Çoğu durumda klinik olarak önemli olmasa da, derin ven trombozu ve pulmoner emboli gibi hayatı tehdit edici, morbiditesi ve mortalitesi yüksek olan klinik durumların ön habercisi de olabilmektedir. Koroner baypas cerrahisi sonrası pulmoner tromboemboli nadir rastlanan komplikasyonlardan biridir. Standart bir tedavi protokolü olmamasına rağmen; erken tanı konulması ve tedavinin erken başlanması başarıı bir sonuç için hayati önem taşımaktadır.

Olgumuz; 63 yaşında erkek hasta, kardiyopulmoner baypas ile koroner arter baypas greftleme ameliyatı yapıldı. Ameliyat sonrası 3. gününde serviste mobilize olurken ani senkop sonrası solunum ve kardiyak arrest gelişti. Hastaya yapılan transtorasik ekokardiyografide sağ ventrikül apeksinde trombüs materyali, spiral bilgisayarlı tomografide ise her iki pulmoner arterde trombüs saptandı. Akut pulmoner emboli tanısı konulan hastaya trombolitik tedavi başlandı. Tedavinin 48. saatinde hastanın klinik ve radyolojik bulgularının düzeldiği gözlendi.

Bu yazımızda, koroner arter baypas ameliyatı sonrası erken dönemde etyolojik nedeninin sağ ventriküldeki trombüs olduğu düşünülen, masif (yüksek riskli) pulmoner emboli gelişen vakada uygulanan trombolitik tedavi ve etkinliğini sunmayı amaçladık.

Anahtar Kelimeler: Koroner arter baypas, pulmoner emboli, trombolitik tedavi

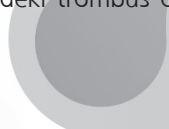

$$
\text { Abstract }
$$

Asymptomatic venous thromboembolism is surprisingly frequent following coronary artery bypass surgery. In most cases, this situation is not clinically important, however it may lead to clinical conditions such as deep venous thrombosis and pulmonary embolism which are life threatening with high morbidity and mortality. Pulmonary thromboembolism following coronary artery bypass surgery is a rare complication. Although there is not a standard therapy protocol, early diagnose and therapeutic approach are vitally important for a successful result.

Sixty three year old male patient was operated coronary artery bypass grafting with cardiopulmonary bypass. Respiratory and cardiac arrest following sudden syncope occured during mobilization on the 3rd postoperative day in the inpatient clinic. The transthoracic echocardiographic imaging revealed thrombus in the apical segment of the right ventricle, and thrombus in bilateral pulmonary arteries were found in the spiral computerized tomography scan. Thrombolytic therapy was administered with the diagnosis of acute pulmonary embolism. The clinical and radiological findings were resolved on the 48th hour of therapy. In this paper, we aimed to present thrombolytic therapy and its efficiency in a case of massive (high risk) pulmonary embolism in the early postoperative period following coronary artery bypass surgery for which the ethiologic factor was thought to be the thrombus in the right ventricle.

Keywords: Coronary artery bypass, pulmonary embolism, thrombolytic therapy 


\section{Introduction}

Pulmonary embolism (PE) is a cardiovascular emergency situation which is relatively frequent. This may lead to acute and life threatening but potentially reversible right ventricular failure due to thrombotic occlusion of pulmonary arterial bed. ${ }^{1}$ $\mathrm{PE}$ following coronary arterial bypass grafting $(C A B G)$ is a rare complication which results in high morbidity and mortality rates. The incidence of asymptomatic venous thromboembolism (VTE) following CABG operation is $15-20 \%$ and the possibility of PE to occur in these patients is reported as $0.5-4 \%$.2

Since PE does not appear with a particular clinic presentation, the diagnose is difficult and may not be noticeable. However, early diagnosis is very important regarding the extreme efficiency of early onset therapy. According to clinical presentation, the initial therapy primarily aims to either save life by resupplying blood flow throughout occluded pulmonary arteries or prevent from potentially mortal early recurs. Therapeutic options like catheter embolectomy, thrombolytic therapy and open pulmonary embolectomy are used for the treatment of PE recently. ${ }^{3}$

In this paper, we aimed to present the efficiency of thrombolytic therapy and recovery period in a case of massive (high risk) pulmonary embolism in the early postoperative period following coronary artery bypass surgery for which the ethiologic factor was thought to be the thrombus in the right ventricle.

\section{Case Presentation}

Sixty three-year-old male patient with coronary artery disease and risk factors of diabetes, hypertension and smoking, underwent four vessels onpump-CABG. Left internal mammarian artery and right saphenous vein were used as grafts. The preoperative transthoracic echocardiograpy showed normal left ventricular functions with an ejection fraction of $62 \%$. The operation was uneventful. The aortic cross clamp and cardiopulmonary bypass (CPB) durations were 52 and 73 minutes respectively. The patient whose follow up continued in the intensive care unit was extubated in the 4th postoperative hour and was taken to the inpatient room on the first postoperative day. His vital signs were stable in the inpatient clinic follow up period and he was mobilized. Respiratory and cardi- ac arrest following sudden syncope occured during mobilization on the 3rd postoperative day. The patient was emergently intubated and sucessful external resuscitation was done for a short period of time. The patient recovered and was taken to the intensive care unit where he was connected to mechanical ventilator. At that time, sinusal tachycardia with a heart rate of $130 \mathrm{bpm}$, ST segment changes and T-wave negativity (Figure 1) was present. Inotropic agents were started for the patient whose arterial pressure was 90/60 $\mathrm{mmHg}$.

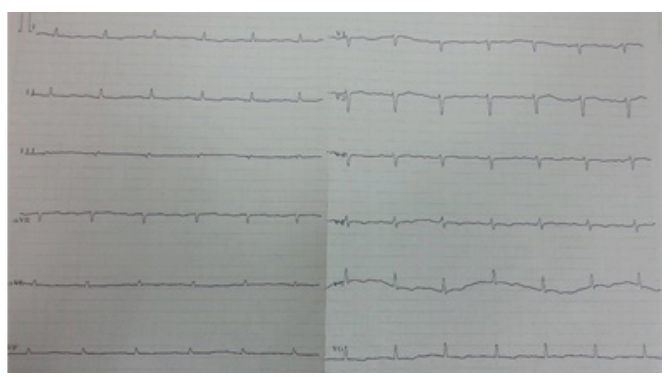

Figure 1: ECG following PE

His body temperature was $36.1^{\circ} \mathrm{C}$. The blood gas analysis showed an oxygen saturation of $80.8 \%$, partial oxygen pressure $(\mathrm{PaO} 2)$ of $45.7 \mathrm{mmHg}$, partial carbondioxyde ( $\mathrm{PaCO} 2)$ of $29.7 \mathrm{mmHg}$ and $\mathrm{pH}$ of 7.56. The whole blood count showed $12.800 / \mathrm{mm} 3$ leucocytes, $32.4 \%$ of hematocrit and $10.8 \mathrm{~g} /$ $\mathrm{dl}$ of hemoglobin. D-dimer level was found high (10,035 ng/ $\mathrm{ml}$ ). There was linear atelectasia on bilateral middle and low pulmonary zones in direct telecardiographic imaging (Figure 2). The transthoracic echocardiography showed normal left ventricular systolic and diastolic diameters and a global ejection fraction of $55 \%$.

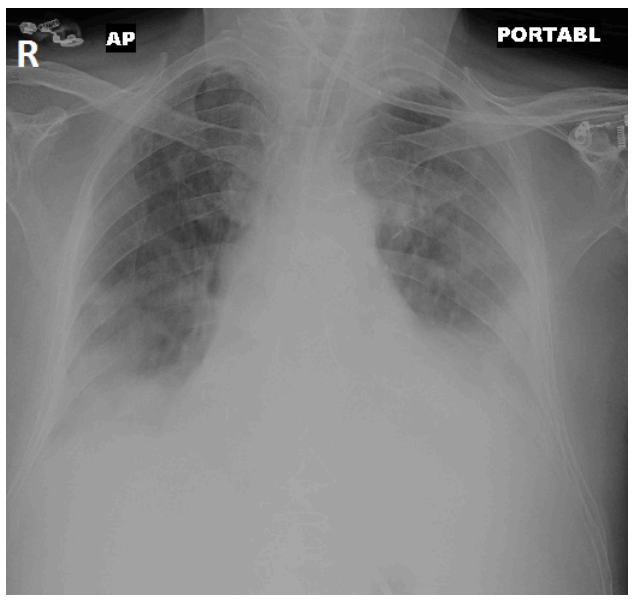

Figure 2:

Anteroposterior chest X-ray image prior to thrombolytic therapy 
The right heart spaces were larger than normal with right ventricle apex being hyperkinetic and the rest of the right ventricle being akinetic (McConnell sign). A material filling the right ventricle apex with the same echogenity as a thrombus was found (Figure 3).

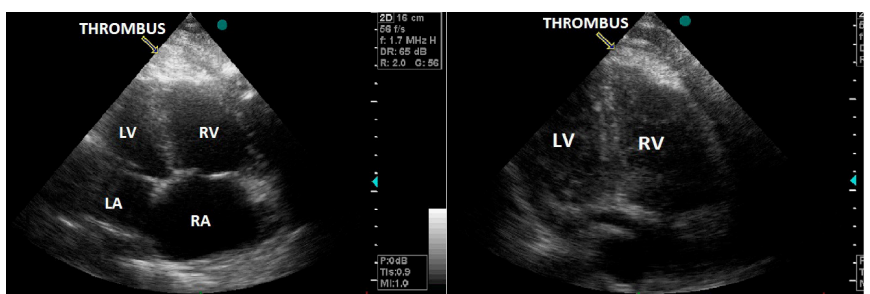

Figure 3: Apical thrombus image in the right ventricle with transthoracic echocardiography

Thrombus material in the lumen of common pulmonary artery beginning from the bifurcation, extending to both of the pulmonary arteries prominently on the right side with a partial filling defect and reaching the lobar and segmentary arteries causing a large filling defect was detected by spiral computerized tomography (CT). There was a remarkable pleural effusion on the left side (Figure 4).

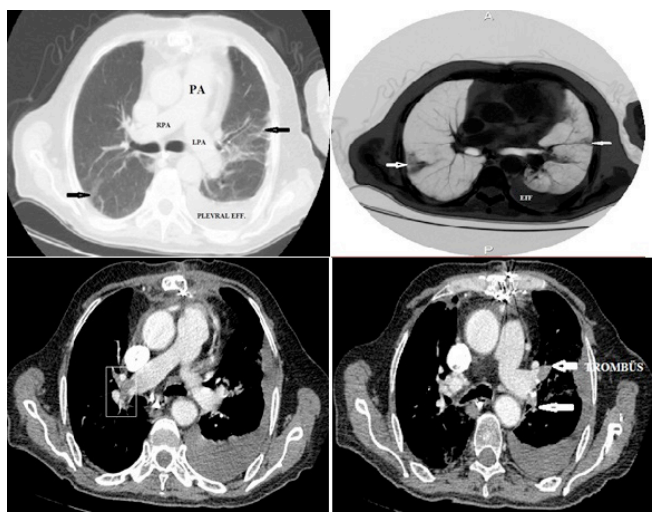

Figure 4: Spiral CT image of the thrombus in the right and left pulmonary arteries

The patient whose definitive diagnosis was PE was consulted with the chest diseases clinic and administration of thrombolytic therapy was decided. Mechanic ventilation support was continued to decrease the risk of bleeding prior to thrombolytic therapy for the patient who was hemodynamically stable. There was no complication due to recombinant tissue plasminogen activator (rt-PA) as thrombolytic in a dose of 50 $\mathrm{mg} /$ hour for 2 hours. Intravenous heparin in a bolus dose of 5000 units was given following the thrombolytic therapy and was continued as an infusion regarding the active clotting time (ACT) to remain in between 180-200 seconds. Complete sedation was maintained for the patient for 24 hours. The patient whose blood gas analyze parameters recovered was extubated on the 48th hour. Following extubation, oral anticoagulation with warfarin sodium was added to the therapy in a dose of $5 \mathrm{mg}$ per day and this dose was arranged according to an INR level of 2 to 3. The heparin therapy was discontinued on the 4th day. The material with a thrombus-like echogenity in the right ventricular apex was found to disappear in the control echocardiography (Figure 5) and the thrombus in both of the pulmonary arteries were found to be resorbed with spiral CT (Figure 6). The direct thoracal X-ray imaging on the 5th day following the thrombolytic therapy showed the resolution of atelectasia of bilateral lower lung zones (Figure 7). The patient was discharged with oral anticoagulant and antiplatelet drugs on the 7th day of therapy without any problems.

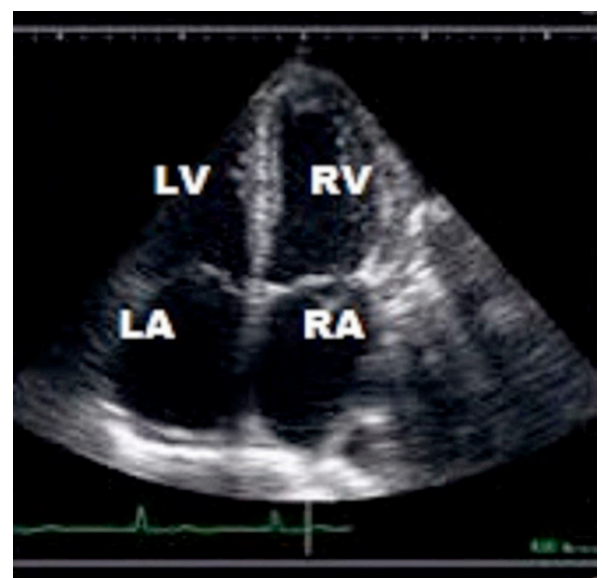

Figure 5: Transthoracic echocardiographic image in the 3rd day following the thrombolytic therapy

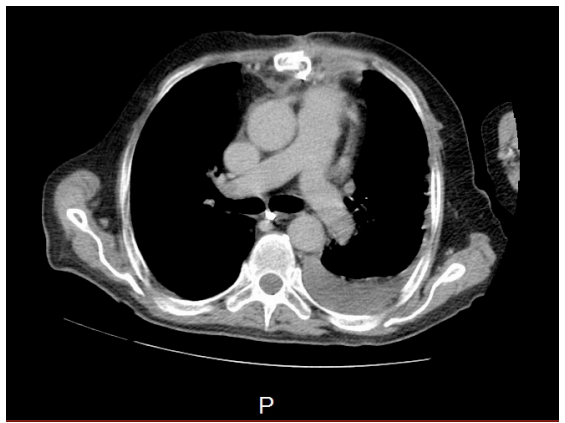

Figure 6: Spiral CT image with intravenous contrast following thrombolytic therapy 


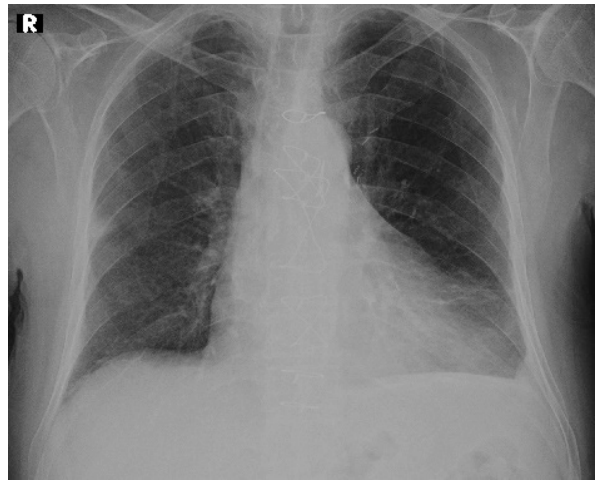

Figure 7: Anteroposterior chest X-ray image after thrombolytic therapy

\section{Discussion}

Pulmonary embolism is a serious disease usually caused by a deep venous thrombosis (DVT) of the lower extremities which shows a broad clinic spectrum from asymptomatic embolism detected coincidentally to massive embolism causing death. At first, factors for tendency to coagulation should be sought in suspicion of PE. Virchow triad which was consisted of local trauma on the vessel wall, hypercoagulability and stasis in blood flow cause thrombosis in the veins of the lower extremity. The thrombus in the lower extremity, pelvis or upper extremity veins may cause embolism in the pulmonary arteries. The most frequent sources of PE are thrombus in the deep veins of the lower extremity and pelvis. ${ }^{4}$ In our case, no thrombus was detected in these veins.

PE is caused by separated thrombus fragments from deep veins which are transferred by the bloodstream to the right ventricle and yet the pulmonary arterial system. This process is characterized by acute occlusion of the pulmonary arterial system. Forty percent of the ethiology of PE is DVT. Ninety percent of the source for embolism is lower extremities and the rest is upper extremities and the heart itself. ${ }^{4}$ In our case, we suppose that the apical thrombus in the right ventricle detected with echocardiography was the cause for PE.

The clinic presentation of PE is divided into three; massive, submassive and non-massive. There is an acute right ventricular failure along with hypotension-shock or cardiopulmonary arrest in massive PE. There are signs of right ventricular dysfunction (dilatation and hypokinesia) in echocardiography despite a normal blood pressure in submassive PE. The blo- od pressure and right ventricle functions are normal in nonmassive PE. ${ }^{4}$ In our case, cardiac arrest following syncope occured, therefore a massive PE was present.

Diagnosis of PE can be made by clinical signs and symptoms, radiologic studies, ventilation/perfusion scintigraphy, angiography and echocardiography. Pulmonary angiography is a gold standard method for PE. However, this is an invasive and expensive method, therefore the patients with suspicion of PE should be evaluated with non-invasive methods at first. In parallel with the recent technologic developments, usage of spiral CT to detect the thrombus mainly in the common pulmonary artery is widespread. The specifity and sensitivity of spiral CT is very high. ${ }^{5}$

Suspicion of PE emerges from clinical signs like dyspnea, chest pain or syncope seen together or individually in $90 \%$ of the patients. Dyspnea, tachypnea or chest pain are reported in more than $90 \%$ of the patients in some series. One of the most common signs of PE is pleurytic chest pain itself or together with dyspnea. Syncope is a rare but important sign of PE which may be an indicator of hemodynamic reserve. There may be shock and arterial hypotension in severe cases. Approximately $10 \%$ of the patients result in death in the following one hour of the initial symptoms; most of the deadly cases can not be clinically diagnosed. Five-10 of PE cases begin with shock or hypotension, whereas laboratory findings showing right ventricular dysfunction which indicate poor prognosis are found without a shock in $50 \%$. Most of the deaths $(>90 \%)$ occur in patients which can not be diagnosed as PE and be treated . 6

Thrombolytic therapy, catheter embolectomy or open embolectomy are lifesavers in cases with massive PE. Patients appearing with shock or hypotension who have suspicious or confirmed PE need hemodynamic and respiratory support. Randomized studies have consistently proved that thrombolytic therapy quickly resolves thromboembolic occlusion and produces a beneficial effect over hemodynamic parameters. Streptokinase, urokinase and rt-PA are agents for thrombolytic therapy. Approximately $92 \%$ of the patients show a response of clinic and echocardiographic recovery in the first 36 hours of thrombolytic therapy. The highest benefit can be 
seen if the tehrapy is started in the first 48 hours of the initial signs ?

The most fearsome complication of thrombolytic therapy is bleeding. Intensive follow up of the patients particularly for intracranial bleeding is necessary. Bleeding is rather like minor bleeding mostly from vessel puncture sites and can be stopped by compression. Incidence of major bleeding is reported as $6.3 \%$, intracranial bleeding as $1.8 \%$ and death due to this as $0.6 \% .{ }^{7}$ In our case, there were no complications during and after the thrombolytic therapy.

Rafique and colleagues administered rt-PA to the proximal of pulmonary thrombus via catheterization in patients with massive acute PE and showed no difference than intravenous infusion method regarding clot resolution and pulmonary arterial pressure decrease. However, they reported that intrathrombus lysis and mechanical disintegration of the clot with a guidewire by placement of the catheter inside the thrombus (pharmacomecaniclysis) was much advantageous. ${ }^{8}$

Anticoagulation plays a very important role in treatment of the patients with PE. The initial anticoagulation in PE aims to prevent death and recurrent embolism despite the acceptable complications of bleeding. Taking into account the high mortality rates in untreated patients, anticoagulation therapy should be considered when waiting for definitive diagnosis in patients with suspicion of PE. Unfractioned heparin dose should be arranged to quickly reach and keep up with the active partial throomboplastin time (aPTT) extension (1.5 to 2.5 times the control level) equivalent to therapeutic heparin levels. Vitamin-K antagonists should be started in the early term, and if possible, together with the initial anticoagulation therapy for maintenance therapy. As soon as the international normalized ratio (INR) reached to 2-3 for a series of 2 days at least, parenteral anticoagulation should be discontinued ${ }^{9}$

Wearing compression socks is beneficial for prevention of relapses after thrombosis. Therefore, it must be applied particularly to immobile patients. ${ }^{10}$

In conclusion, anticoagulation with unfractioned or low molecular weight heparin should be started without any delay during the diagnostic process for patients with confirmed PE or clinical possibility of high grade (massive) or medium grade (submassive) PE. Coronary bypass grafting operated patients usually have damage in their vascular structures of the lower extremity due to usage of the saphenous vein as graft. All of these factors and prolonged immobilization increase the possibility of DVT in these patients. Measures taken for prevention of PE and DVT are much easier and cheaper than diagnose and therapy. Therefore, both mechanical and pharmacological precautions taken against venous thromboembolism and PE may reduce mortality and morbidity in patients particularly with history of $C A B G$ operations and risk factors. ${ }^{4}$

As a result, the reason for PE in the early term following CABG surgery is usually the DVT in the lower extremities. PE with an intracardiac origin, which is the case in current patient, is rarely seen. Although there is not a standard therapy, accurate diagnosis and quick start of therapy is vital for a successful result. PE should be kept in mind for patients who develop sudden syncope and cardiac arrest, and non-invasive methods like echocardiography and spiral CT should be performed for early diagnosis. When there is no contraindication, thrombolytic therapy should be started at first to ensure blood flow inside the occluded pulmonary artery. Patients should be closely monitored in the intensive care unit in terms of bleeding complications. 
1. Roy PM, Meyer G, Vielle B, Le Gall C, Verschuren $\mathrm{F}$, Carpentier $\mathrm{F}$ et al. Appropriateness of diagnostic management and outcomes of suspected pulmonary embolism. Ann Intern Med 2006;144:157-164.

2. Goldhaber SZ, Hirsch DR, MacDougall RC, Polak JF, Creager MA, Cohn LH. Prevention of venous thrombosis after coronary artery bypass surgery (a randomized trial comparing two mechanical prophylaxis strategies). Am J Cardiol 1995;76:993-996

3. Reis SE, Polak JF, Hirsch DR, Cohn LH, Creager MA, Donovan $\mathrm{BC}$ et al. Frequency of deep vein thrombosis in asymptomatic patients with coronary artery bypass grafs. Am J Cardiol 1991;122:478-482

4. Heit JA. The epidemiology of venous thromboembolism in the community: implications for prevention and management. J Thromb Thrombolysis 2006;21: 23-29.

5. Kara I, Ay Y, Aydın C, Kahraman Ay N, Yildırım $\mathrm{T}$ : [Pulmonary embolism be caused by deep venous thrombosis after coronary artery bypass grafting]. Medical Journal of Kocaeli 2012;3:27-30.

6. Laporte S, Mismetti P, Decousus H, Uresandi F, Otero R, Lobo $\mathrm{JL}$, et al. Clinical predictors for fatal pulmonary embolism in 15,520 patients with venous thromboembolism: findings from the Registro Informatizado de la Enfermedad TromboEmbolica venosa (RIETE) Registry. Circulation 2008;117:1711-1716.

7. Meneveau N, Séronde MF, Blonde MC, Legalery P, DidierPetit K, Briand F, et al. Management of unsuccessful thrombolysis in acute massive pulmonary embolism. Chest $2006 ; 129: 1043-1050$.

8. Rafique $M$, Middlemost $S$, Skoularigis J, Sareli $P$. Simultaneous mechanical clot fragmentation and pharmacologic thrombolysis in acute massive pulmonary embolism. Am J Cardiol 1992;69:427-430.

9. Torbicki A, Perrier A, Konstantinides S, Agnelli G, Galiè $N$, Pruszczyk $P$, et al. Guidelines on the diagnosis and management of acute pulmonary embolism: the Task Force for the Diagnosis and Management of Acute Pulmonary Embolism of the European Society of Cardiology (ESC). Eur Heart J 2008;29:2276-2315.

10. Wittine LM, Auger WR. Chronic Thromboembolic Pulmonary Hypertension. Curr Treat Options Cardiovasc Med 2010;12:131-141. 